\title{
Cymothoa indica (Crustacea, Isopoda, Cymothoidae) parasitizes the cultured larvae of the Asian seabass Lates calcarifer under laboratory conditions
}

\author{
M. Rajkumar ${ }^{1}$, P. Perumal' ${ }^{1}$, J. P. Trilles ${ }^{2, *}$ \\ ${ }^{1}$ Centre of Advanced Study in Marine Biology, Annamalai University, Parangipettai 608 502, Tamil Nadu, India \\ ${ }^{2}$ UMR 5171 (UM2-IFREMER-CNRS) (Génome, Populations, Interactions, Adaptations), Equipe Adaptation Ecophysiologique \\ et Ontogenèse, Université Montpellier II, CP 092, Place Eugène Bataillon, 34095 Montpellier Cedex 5, France
}

\begin{abstract}
Parasitic disease in fishes is one of the most important factors limiting aquaculture production and its economic viability. Cymothoa indica, a cymothoid isopod, is reported here for the first time parasitizing cultured larvae of the Asian seabass Lates calcarifer in India. Fourteen-day-old L. calcarifer larvae of mean weight $8.73 \pm 0.03 \mathrm{mg}$ were fed with wild zooplankton in the laboratory. On Day 14 of rearing, larvae were found parasitized by cymothoids. Infected larvae reached a mean $( \pm \mathrm{SE}$ ) weight of $98.86 \pm 0.30 \mathrm{mg}$, while uninfected specimens weighed $117 \pm 0.43 \mathrm{mg}$ at the end of the experiment (Day 21). C. indica occurred in the branchial and anterodorsal regions of infected fish, where resultant skin lesions were red, hemorrhagic, without scales and with abundant secreted mucus. The cumulative mortality over the 3 wk period was $16.54 \%$. These parasites are transferred to the host via the zooplankton used as food; this could easily be overcome, either by filtering wild zooplankton to remove the infectious swimming larvae of $C$. indica or by using cultured copepods.
\end{abstract}

KEY WORDS: Cymothoid $\cdot$ Isopod $\cdot$ Parasite $\cdot$ Cymothoa indica $\cdot$ Lates calcarifer $\cdot$ Larvae $\cdot$ India

\section{INTRODUCTION}

Parasitic diseases in fishes seriously limit aquaculture production and its economic viability. Knowledge of fish diseases and parasites is essential for successful aquaculture, particularly in a country like India with long and highly productive coastal waters. However, the tropical coastal and brackish waters, which likely contain many unknown parasites and pathogens, are poorly studied.

Many diverse animal species ranging from protozoans to crustaceans, have important economic impacts as parasites of finfish and shellfish (Reichenbach-Klinke et al. 1968). The pathological conditions resulting from parasitic infection often reach a significant extent under both natural and controlled condi- tions in aquaculture. Loss of weight, loss of fat content and changes in the water content of various tissues affect growth, metabolism, reproduction and visceral mass, and also result in abnormal behavior of the host (Lester \& Roubal 1995).

The commercial aspects of harvesting fishes and crustaceans are greatly influenced by the presence of parasitic isopods on these hosts. As fish and decapod farming become more widespread, the effects of parasitic isopods should become more apparent (Kabata 1984). Loss of weight reduces the volume of the catch without reducing the number of fish; poor quality fish are less acceptable to the customer (Sinderman 1958, Sparks 1972, Murchalam 1980), resulting in economic losses and reduced fish landings in many coastal waters. 
In most cases, parasitic isopods are blood feeders and, thus, nutritionally dependent on their hosts (Pillai 1958, Trilles 1969, Bunkley-Williams \& Williams 1998). Cymothoids occur on the body, in the mouth or in the branchial cavity of the host fish; their position is thus often highly specific (Trilles 1969). They cause several pathogenic effects upon the organs and growth rate of the host (Kroger \& Guthrie 1972, Sadzikowski \& Wallace 1974, Lanzing \& O'Connor 1975, Brusca 1978, Romestand 1979, Romestand \& Trilles 1977a,b, 1979, Bragoni et al. 1983, 1984, Kabata

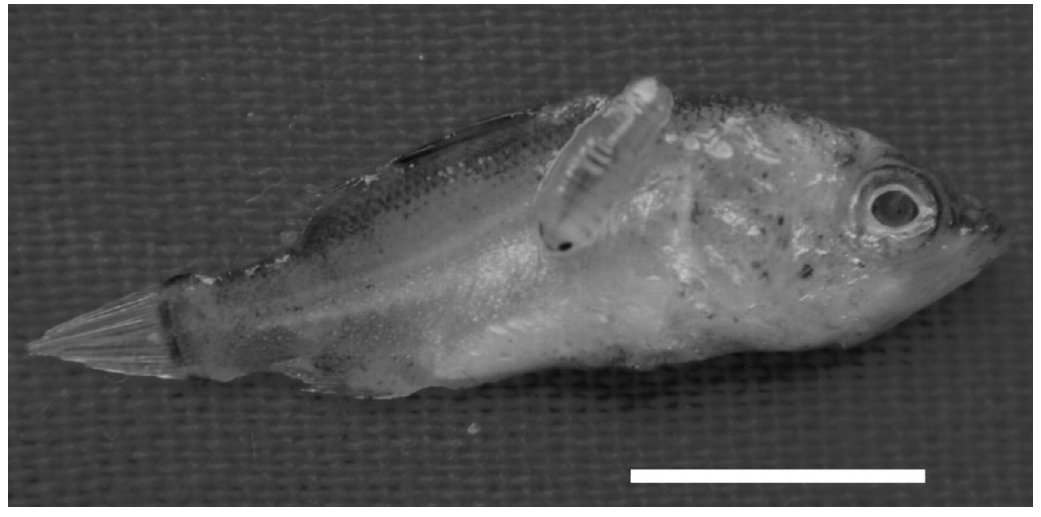

Fig. 1. Cymothoa indica settled on the body surface of the cultured seabass Lates calcarifer. Scale bar $=50 \mathrm{~mm}$

(Decoplast) $\left(\begin{array}{ll}50 & 1\end{array}\right)$ filled with seawater that was changed daily. In each vessel, we distributed 50 larvae of $L$. calcarifer with a mean $( \pm \mathrm{SE})$ initial body length and initial weight of $6.6 \pm 0.22 \mathrm{~mm}$ and $8.73 \pm 0.03 \mathrm{mg}$, respectively. The cultured specimens were fed with wild zooplankton, especially copepods, given in 3 equal rations daily at 07:30, 14:00 and 20:30 h.

\section{RESULTS}

On Day 14 of rearing, the Lates calcerifer larvae (28 d old; mean [ $\pm \mathrm{SE}] 15 \pm 0.02 \mathrm{~mm}$ long) were found parasitized by cymothoids. At the end of the experiment (i.e. after $21 \mathrm{~d}$ ), the cultured specimens of seabass (35 d old) suffered serious mortalities; infected larvae reached a mean body length and weight of $37.13 \pm$ $0.05 \mathrm{~mm}$ and $98.86 \pm 0.30 \mathrm{mg}$, respectively, while for uninfected specimens these were $60.18+0.03 \mathrm{~mm}$ and $134.27 \pm 0.01 \mathrm{mg}$, respectively. The dead or moribund seabass were collected; many parasitic larvae were removed from the body and identified as Cymothoa indica, following the description of Veerapan \& Ravichandran (2000) (Fig. 2).

Infections extended over $21 \mathrm{~d}$, with a cumulative mortality of $16.54 \%$. Parasitic larvae settle particularly in the branchial and anterodorsal region of the host fish, where red, hemorrhagic skin lesions, without scales and with abundant secreted mucus, were observed. The usual clinical signs include erratic swimming behavior, decrease in growth and loss of weight, with death resulting from severe anaemia and anorexia (Romestand \& Trilles 1977a, Horton \& Okamura 2003) and osmotic stress (Papapanagiotou et al. 1999). Secondary infections are quite likely, although with reference to some species of Riggia and Artystone, Thatcher (2000) suggested dubitatively that the isopods secrete an antibiotic substance which inhibits the growth of bacteria and fungi. 


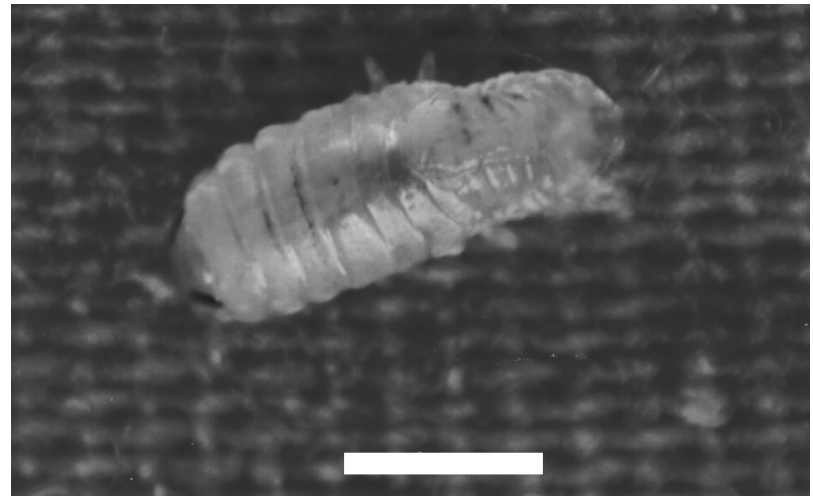

Fig. 2. A larva of Cymothoa indica; dorsal view. Scale bar $=$ $0.75 \mathrm{~mm}$

\section{DISCUSSION}

Prior to this study, Nematolosa nasus (Clupeiformes, Clupeidae) and Siganus javus (Perciformes, Siganidae) fed with wild food were found parasitized by Cymothoa indica (M. Rajkumar pers. obs.). Veerapan \& Ravichandran (2000) reported a similar parasitic infection of wild populations of Sphyraena obtusata (Perciformes, Sphyraenidae) and Trachinocephalus myops (Aulopiformes, Synodontidae). Rajkumar et al. (2004) observed a severe infection by Cymothoa indica in the buccal cavity of the spot-tail needlefish Strongylura strongylura (Beloniformes, Belonidae). Recently, this isopod has been reported parasitizing the longwhiskered catfish Mystus gulio (Siluriformes, Bagridae) cultured in experimental cages in India (Rajkumar et al. 2005). Therefore, no other reports about cymothoid infection of $L$. calcarifer and on such parasitic infection of fish larvae in general were available at the time of this study.

Under culture conditions, modified specificity is exhibited by some parasites (isopods, copepods, monogeneans); these parasites are never present on wild populations of host species, whereas reared individuals of the same species are infected (Raibaut et al. 1980, Euzet \& Raibaut 1985, Cabral \& Raibaut 1987 , Cassier et al. 1998). Optimal management of the system (low stocking density, chemical and physical surveillance of sites, optimum farming practices) should be applied to reduce handling stress and unsuitable conditions that inevitably increase the susceptibility to pathogens and induce immunosuppression. It is common knowledge in the aquaculture industry that under stressful conditions ubiquitous parasites become major pathogens.

The first report of a cymothoid infection in an aquaculture system is that of Nerocila orbignyi infecting the seabass Dicentrarchus labrax (Perciformes, Moro- nidae) reared in Diana pond in Corsica (Bragoni et al. 1983, 1984). Subsequently, several species were found to infect many cultivable fishes, inducing severe mortalities and consequent economic losses in commercial farming facilities (Bragoni et al. 1983, 1984, Roa 1992, Cassier et al. 1998, Papapanagiotou et al. 1999, Papapanagiotou \& Trilles 2001, Rajkumar et al. 2005).

Several management practices to control the parasitic cymothoids on cultured fishes have been discussed (Bragoni et al. 1983, 1984, Roa 1992, Papapanagiotou et al. 1999, Papapanagiotou \& Trilles 2001, Rajkumar et al. 2005). Parasites are transferred to cultured specimens from wild populations of fishes. Thus, for example, transfer from wild mullet to cultured seabass Dicentrarchus labrax is possible under some conditions, as reported by Bragoni et al. (1983, 1984). In the case of Cymothoa indica parasitizing cultured larvae of Lates calcarifer, infectious larvae are certainly transferred to the Asian seabass through wild zooplankton used as food. Therefore, in place of wild zooplankton, it is desirable and recommended to use cultured copepods to prevent parasites from reaching the larval culture system in this way. Alternatively, wild zooplankton can be filtered through a net with a mesh size of $500 \mu \mathrm{m}$ to retain the infectious swimming larvae of $C$. indica, which are more than $1.5 \mathrm{~mm}$ long and $600 \mu \mathrm{m}$ wide.

Acknowledgements. The authors are grateful to the Authorities of Annamalai University (India) for the facilities provided and to the Indian Council of Agricultural Research for financial support. We also thank the reviewers, Dr. Kabata and anonymous, for their comments which substantially improved this article.

\section{LITERATURE CITED}

Adlard RD, Lester RJG (1995) The life cycle and biology of Anilocra pomacentri (Isopoda: Cymothoidae), an ectoparasitic isopod of the coral reef fish Chromis nitida (Perciformes: Pomacentridae). Aust J Zool 43:271-281

Bragoni G, Romestand B, Trilles JP (1983) Parasitoses à Cymothoadien chez le loup Dicentrarchus labrax (Linnaeus, 1758) en élevage. II. Ecophysiologie parasitaire dans le cas de l'étang de Diana (Haute-Corse). Ann Parasitol Hum Comp 58(6):593-609

Bragoni G, Romestand B, Trilles JP (1984) Parasitoses à Cymothoadien chez le loup Dicentrarchus labrax (Linnaeus, 1758) en élevage. I. Ecologie parasitaire dans le cas de l'étang de Diana (Haute-Corse) (Isopoda, Cymothoidae). Crustaceana 47(1):44-51

Brusca RC (1978) Studies on the cymothoid fish symbionts of the eastern Pacific (Isopoda, Cymothoidae) I. Biology of Nerocila californica. Crustaceana 34(2):142-154

Bunkley-Williams L, Williams EH Jr (1998) Isopods associated with fishes: a synopsis and corrections. J Parasitol 84: 893-896

Cabral P, Raibaut A (1987) Découverte d'un Copépode Caligide nouveau parasite du tégument du loup Dicentrarchus 
labrax (L., 1758) (Pisces, Moronidae) en élevage et en milieu naturel. Bull Soc Zool Fr 111(1-2):123-130

Cassier P, Brugerolle G, Combes C, Grain J, Raibaut A (1998) Le parasitisme. Un équilibre dynamique. Masson, Paris

Euzet L, Raibaut A (1985) Les maladies parasitaires en pisciculture marine. Symbioses 17:51-68

Horton T, Okamura B (2001) Cymothoid isopod parasites in aquaculture: a review and case study of a Turkish sea bass (Dicentrarchus labrax) and sea bream (Sparus auratus) farm. Dis Aquat Org 46:181-188

Horton T, Okamura B (2003) Post-haemorrhagic anaemia in sea bass, Dicentrarchus labrax (L.), caused by blood feeding of Ceratothoa oestroides (Isopoda: Cymothoidae). J Fish Dis 26:401-406

Kabata Z (1984) Diseases caused by metazoans: crustaceans. In: Kinne O (ed) Diseases of marine animals. IV (I). Biologische Anstatt Helgoland, Hamburg, p 321-399

Kent ML (2000) Marine netpen farming leads to infections with some unusual parasites. Int J Parasitol 30(3):321-326

Kroger RL, Guthrie JF (1972) Incidence of the parasitic isopod, Olencira praegustator, in juvenile Atlantic menhaden. Copeia 2:370-374

Lanzing WJR, O'Connor PF (1975) Infestations of luderick (Girella tricuspidata) populations with parasitic isopods. Aust J Mar Freshw Res 26:355-361

Lester RJG, Roubal FR (1995) Phylum Arthropoda. In: Woo PTK (ed) Fish diseases and disorders, Vol 1. Protozoan and metazoan infections. CAB International, Wallingford, p 475-598

Lobos BCI (1994) Accion del isopodo Ceratothoa gaudichaudii sobre el peso corporal de salmones del Atlantico (Salmo salar). Tesis de grado de Licenciado en Medicina veterinaria, Universidad austral de Chile, Facultad de ciencias veterinarias, Valdivia

Moser M, Sakanari J (1985) Aspects of host location in the juvenile isopod Lironeca vulgaris (Stimpson, 1857). J Parasitol 71:464-468

Murchalam RA (1980) Environmental quality the diseases of fish and shell fish. Maritimes 12:1-5

Östlund-Nilsson S, Curtis L, Nilsson GE, Grutter AS (2005) Parasitic isopod Anilocra apogonae, a drag for the cardinal fish Cheilodipterus quinquelineatus. Mar Ecol Prog Ser 287:209-216

Papapanagiotou EP, Trilles JP (2001) Cymothoid parasite Ceratothoa parallela inflicts great losses on cultured gilthead sea bream Sparus aurata in Greece. Dis Aquat Org 45: 237-239

Papapanagiotou EP, Trilles JP, Photis G (1999) First record of Emetha audouini, a cymothod isopod parasite, from cultured sea bass Dicentrarchus labrax in Greece. Dis Aquat Org 38:235-237

Pillai NK (1958) Tanaidacea and Isopoda of Travancore. PhD thesis, University of Kerala, Thiruvananthapuram

Raibaut A, Divanach P, Coste F, Maillard C (1980) Copépodose larvaire en écloserie de poissons marins. La Piscicult Fr 61/62:49-51

Rajkumar M, Santhanam P, Perumal P (2004) Report on new host record of Cymothoa indica (Schioedte and Meinert, 1884) (Crustacea: Isopoda) from Parangipettai coastal waters, southeast coast of India. J Aquat Biol 19(2): 113-114

Rajkumar M, Kumaraguru KP, Perumal P, Trilles JP (2005) First record of Cymothoa indica (Crustacea, Isopoda, Cymothoidae) infecting the cultured catfish Mystus gulio in India. Dis Aquat Org (in press)

Reichenbach-Klinke W, Braun F, Held H, Riedmuller S (1968) Vorläufige Ergebnisse Vergleichender-physiologischer
Untersuchungen an Coregonen verschiedener Oberbayerischer Seen (Fettgehatt, Blutbild, Fermentspiegel, Parasitisierung). Arch Fischwiss 19:114-130

Roa RJE (1992) Contribution al estudio del isopodo Ceratothoa gaudichaudii como parasito de salmones (Salmo salar) cultivados en aqua de mar en dos centros de cultivo de la provincia de Llanquihue. Tesis de grado de Licenciado en Medecina veterinaria, Universidad austral de Chile, Facultad de ciencias veterinarias, Valdivia

Romestand B (1979) Etude écophysiologique des parasitoses à cymothoadiens. Ann Parasitol Hum Comp 54(4):423-448

Romestand B, Trilles JP (1977a) Influence des cymothoadiens (Crustacea, Isopoda, Flabellifera) sur certaines constantes hematologiques des poissons hôtes. Z Parasitenkd 52: 91-95

Romestand B, Trilles JP (1977b) Dégénérescence de la langue des bogues (Boops boops L., 1758) (Téléostéens, Sparidae) parasitées par Meinertia oestroides (Risso, 1826) (Isopoda, Flabellifera, Cymothoidae). Z Parasitenkd 54:47-53

Romestand B, Trilles JP (1979) Influence des cymothoadiens Meinertia parallela et Anilocra physodes (Crustacés, Isopodes; parasites de poissons) sur la croissance des poissons hôtes Boops boops et Pagellus erythrinus (Sparidés). Z Parasitenkd 59: 195-202

Sadzikowki MR, Wallace DC (1974) The incidence of Lironeca ovalis (Say) (Crustacea, Isopoda) and its effects on the growth of the white perch, Morone americana (Gmelin), in the Delaware River near Artificial Island. Chesapeake Sci 15:163-165

Sarusic G (1999) Preliminary report of infestation by isopod Ceratothoa oestroides (Risso, 1826), in marine cultured fish. Bull Eur Assoc Fish Pathol 19:110-112

Segal E (1987) Behavior of juvenile Nerocila acuminata (Isopoda, Cymothoidae) during attack, attachment and feeding on fish prey. Bull Mar Sci 41:351-360

Sievers G, Lobos C, Inostroza R, Ernst S (1996) The effect of the isopod parasite Ceratothoa gaudichaudii on the body weight of farmed Salmo salar in Southern Chile. Aquaculture 143:1-6

Sinderman CJ (1958) An epizootic in Gulf of Saint Lawrence fishes. Trans N Am Wildl Nat Resour Conf 23:349-360

Sparks AK (1972) Invertebrate pathology of non communicable disease, Academic Press, New York

Thatcher VE (1988) Asotana magnifica n. sp. (Isopoda, Cymothoidae) an unusual parasite (commensal?) of the buccal cavities of piranhas (Serrasalmus sp.) from Roraima, Brazil. Amazoniana X:239-248

Thatcher VE (2000) The isopod parasites of South American fishes. In: Salgado-Maldonado G, Garcia Aldrete AN, Vidal-Martinez VM (eds) Metazoan parasites in the neotropics: a systematic and ecological perspective. Instituto de Biologia, Universidad Nacional Autonoma de Mexico, Mexico City, p 193-226

Trilles JP (1969) Recherches sur les isopodes Cymothoidae des côtes françaises. Aperçu général et comparatif sur la bionomie et la sexualité de ces Crustacés. Bull Soc Zool Fr 94(3):433-445

Veerapan N, Ravichandran S (2000) Isopod parasites from marine fishes of Parangipettai coast. UGC-SAP Monograph series, Annamalai University, Parangipettai

Williams EH Jr, Bunkley-Williams L (1994) Four cases of unusual crustacean-fish associations and comments on parasitic processes. J Aquat Anim Health 6:202-208

Wright RV, Lechanteur YARG, Prochazka K, Griffiths CL (2001) Infection of hottentot Pachymetopon blochii by the fish louse Anilocra capensis (Crustacea: Isopoda) in False Bay, South Africa. Afr Zool 36:177-183

Submitted: September 21, 2004; Accepted: March 25, 2005

Proofs received from author(s): July 25, 2005 